\title{
The effects of China's cross-border e-commerce on its exports: a comparative analysis of goods and services trade
}

\author{
Zi Hui Yin ${ }^{1}$. Chang Hwan Choi $^{1}[$
}

Accepted: 6 April 2021 / Published online: 16 April 2021

(C) The Author(s) 2021

\begin{abstract}
This study examines the effects of China's cross-border e-commerce (CBEC) on its goods and services exports to 'Belt and Road' (B\&R) countries for the period 2000-2018 using a gravity model. We find that CBEC has a greater positive impact on trade in services than on trade in goods, especially after the implementation of the B\&R initiative. Furthermore, as the level of CBEC rises, distance tends to have a lower (higher) impact on services (goods) trade, whereas the impact on services (goods) trade increased (decreased) annually. Hence, promoting the sustainable development of CBEC can lead to increased export volumes.
\end{abstract}

Keywords Cross-border e-commerce $\cdot$ Export $\cdot$ Goods trade $\cdot$ Services trade $\cdot$ Belt and road $\cdot$ China

\section{Introduction}

With the spread of the Internet and the progress of digital technology, e-commerce has been booming globally. E-commerce is a concept of trade whereby customers order and pay for products via the Internet, and sellers deliver the products in either a physical or digital form [1,2].

Cross-border e-commerce (CBEC) refers to the international business activities in which individuals or enterprises from different countries utilize e-commerce platforms for payment and settlement transactions and rely on the international logistics system to deliver goods [3, 4]. Suppliers and consumers of CBEC can sell and purchase products through the Internet on a global scale. This generates substantial savings in transaction costs, such as those related to communications, market search, and administration. CBEC is being promoted in developing economies, as it enables exporters to overcome constraints related to limited access to information, isolation of potential markets, and high costs of market entry.

Chang Hwan Choi

hub21@dankook.ac.kr

1 International Trade, Dankook University, Yongin, South Korea 
China's CBEC industry is in an upward trend since 2008. In particular, since the 'Belt and Road' (B\&R) initiative was put forward in 2013, the industry has developed rapidly with the introduction of promotion policies and construction of e-commerce platforms. According to the China's E-Commerce Research Center [5], the total transaction volume of CBEC in China increased from 0.7 trillion yuan in 2008 to 10.5 trillion yuan in 2019 , with an average annual growth rate of nearly $20 \%$. At the same time, CBEC transactions accounted for more than $30 \%$ of total imports and exports in 2019, up from less than 5\% in 2008 [6]. In this context, the rise of CBEC presents a new avenue in which China expands its international trade.

The economic importance of CBEC has drawn attention recently. A portion of the related literature acknowledged that CBEC improves international trade [7-10], while others examined the impact of CBEC on a firm's export performance [11-13]. However, only few studies have compared its effect on trade in goods and services. In particular, as one of the fastest growing markets for CBEC, China's services trade has grown faster than its goods trade has since 2012 (see Fig. 1). Therefore, it is important to identify if CBEC has a different impact on goods and services trade, and thereby enhance its role in international trade.

The aim of this study is to contribute to the CBEC literature by analyzing different CBEC impacts on trade in goods and services, with a focus on China and its trading partners in B\&R countries. Apart from understanding the CBEC effect on trade in goods and services, this study also contributes to the literature by conducting a number of empirical analyses, including (1) policy effect, that is, examining if the implementation of the $B \& R$ initiatives has a different impact on the relationship between CBEC and trade in goods and services; (2) distance effect, that is, examining how CBEC influences the relationship between distance and trade, with a comparison of goods and services trade; (3) time effect, that is, exploring if the impact of CBEC on goods and services trade changes differently

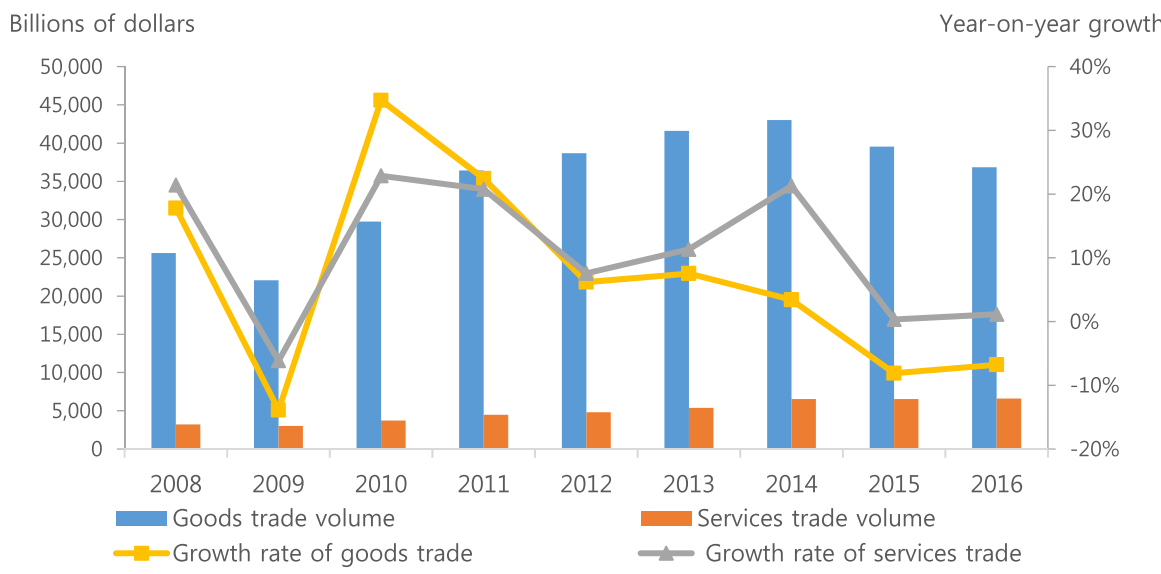

Fig. 1 China's total trade volume in goods and services and their year-on-year growth rates. Source: China's Ministry of Commerce [14] 
over time. To the best of our knowledge, this study is the first to analyze the CBEC impact on goods and services trade in the abovementioned dimensions.

The rest of the paper is structured as follows. We start by presenting the existing literature and propose the hypotheses (Sect. 2). We build the research model, data selection, empirical analysis (Sect. 3), and discuss results (Sect. 4). Finally, we present our conclusions, implications, and future research (Sect. 5).

\section{Literature review and hypotheses}

\subsection{CBEC and international trade}

The application of digital technology has changed the trade pattern, trade structure, and global value chain and has become a new subject of international trade research. A growing number of scholars have attempted to study how digital technologies, such as the Internet and e-commerce, influence trade.

The trade effect of the Internet has been widely examined in a gravity model and most of the studies have acknowledged a positive relationship [15-24]. Using data from transition economies of Central Asia and Eastern Europe, Clarke [15] found that enterprises with access to Internet export more than those without it. The author explained that exports are growing because Internet use has made it easier for enterprises to communicate with foreign buyers, thereby improving access to market information. Freund and Weinhold [16] explored if Internet use has an impact on goods trade. By analyzing data from 56 countries for the period 1995-1999, they found a positive correlation between Internet use and goods exports, with higher impact in developing countries than in developed countries. Using the data from 2006 to 2010 of a large sample of countries, Biswas and Kennedy [20] examined the impact of the Internet on agricultural and non-agricultural exports. Their results show that exports of both types of commodities increase with growing Internet use, with the positive effect of Internet use being stronger for non-agricultural commodities.

More recently, Osnago and Tan [21] used panel data for the period 2001-2013 to examine how Internet adoption by exporters and importers affects intensive margin (i.e., the average value of exports) and extensive margin (i.e., the number of products exported). Their results show that Internet adoption by exporters has a greater impact on the extensive margin compared with the intensive margin, whereas Internet adoption by importers has the opposite outcome. Furthermore, Rodríguez-Crespo and Martínez-Zarzoso [24] examined how Internet use affects trade when differences in knowledge exist between countries. By using bilateral export data from 120 countries from 2000 to 2014, they found that Internet use promotes exports, but the relationship is more sensitive when grouping samples by product complexity than by income levels.

In contrast, several scholars have focused on the link between the Internet and services trade [25-29]. By analyzing bilateral services trade data from the United States and 31 middle- and high-income countries for the period 1995-1999, Freund and Weinhold [25] examined the impact of the Internet on services trade. Their 
findings show that countries with higher Internet use export more services to the United States. In particular, exports in business, professional, and technical services sectors grow more quickly with higher Internet use. Additionally, this positive relationship was supported by Choi [26], Salmani et al. [27], and Nath and Liu [28] using different country samples. Furthermore, Yousefi [29] studied the impact of the Internet on imports and exports of services using data from developed and developing countries between 2000 and 2014. The results show that an increase in internet users promotes the growth of services exports by $0.27 \%$ and services imports by $0.08 \%$. Among them, the Internet has a greater effect on services exports in developed countries $(0.52 \%)$, but has no significant impact on developing countries.

Regarding the effect of CBEC on international trade, Wang et al. [8] used Chinese data for the period 2011-2015, and found that CBEC development increases the total volume of international trade. Specifically, a $1 \%$ rise in $\mathrm{CBEC}$ will increase total trade volume by approximately $0.6 \%$. Danquah and Chen [30] explored causal relationships between e-commerce, imports, and exports in China and the United States. Their results show that bidirectional causality only exists in the United States, suggesting that the United States can benefit from policies that promote e-commerce and their foreign sectors. Xing [9] explored the trade effect of business-to-business (B2B) and business-to-consumer (B2C) adoption separately using a large country-level dataset. The author reported that a $1 \%$ increase in the adoption of $\mathrm{B} 2 \mathrm{~B}$ e-commerce led to a $0.068 \%$ growth in exports, whereas a $1 \%$ increase in the adoption of $\mathrm{B} 2 \mathrm{C}$ e-commerce led to a $0.004 \%$ growth in exports. In contrast, at the firm level, Burinskiene [12] developed a framework of the growth of international trade capacity for EU-based enterprises. The author reported that improving the ability to use e-commerce is important to promote international trade as the use of e-commerce reduces the dependence of buyers and sellers on location, and expands the variety of products that can be traded. Using Chinese firm-level data for the period 2000-2009, Yue and Li [13] explored the effect of e-commerce platforms on exports for manufacturing firms. By conducting analysis on multiple dimensions, they found that an e-commerce platform increases both the probability of enterprises entering the export market and export volumes of exporters. The mechanism of the export promotion effect is explained as follows: the application of e-commerce platforms improves enterprise productivity, matches buyers and sellers more effectively, and reduces the entry threshold for the export market.

In summary, many studies have addressed the effects of the Internet or e-commerce on international trade in an individual country or in a large country sample. However, empirical studies focusing on the CBEC impact on international trade between China and B\&R countries are scarce. Therefore, in this study, we examine the CBEC trade effects with a focus on China and its trading partners in B\&R countries. China's B\&R project aims to support trade co-operation among various countries, including Asian, African, and European countries. In particular, under the $\mathrm{B} \& \mathrm{R}$ initiative, the Chinese government has introduced many promotion policies to enhance the development of CBEC to promote trade with B\&R countries [4]. Mou et al. [31], Li et al. [32], and Wang et al. [33] also emphasized that the B\&R initiative promotes the development of $\mathrm{CBEC}$ and provides more opportunities for Chinese firms to export their products and services to overseas markets. Hence, it 
is reasonable to predict that the development of CBEC in China will have an impact on its export volume with B\&R countries. In addition, few studies have compared the CBEC effect on goods trade and services trade. As mentioned by Clarke [15], Freund and Weinhold [16], and Yousefi [29], digital technology affects goods trade because it improves information about foreign markets, thus, reducing market entry costs. Compared with goods trade, the impact of digital technology on services trade is relatively greater, because new services transferred via the Internet can be traded almost costless, irrespective of location. This implies that digital technology has different effects on trade in goods and services. Therefore, this study aims to examine if and how CBEC affects trade in goods and services differently.

To the best of our knowledge, this is the first study to examine how China's CBEC affects its exports to B\&R countries, with a comparative study of goods and services trade.

\subsection{Hypotheses}

Transaction costs, defined by Coase [34], are the costs incurred by traders to obtain accurate market information and negotiate contracts. Butter and Mosch [35] acknowledged that three stages of transaction contribute to the transaction costs: (1) the contact phase, which includes search and information costs for product quality, price, and the reliability of potential trading partners; (2) the contract phase, in which transaction costs are incurred in negotiating the terms of the contract; and (3) the control phase, which involves costs for monitoring and enforcing the contract to ensure that the other party adheres to the contract terms. Furthermore, Wang et al. [8] identified different types of transaction costs in international trade, which include information, negotiation, middlemen, transportation, and tariffs cost.

Some studies have acknowledged that CBEC reduces transaction costs, increases trade efficiency, and generates competitive advantages. First, through CBEC platforms, acquiring information for both sellers and buyers becomes easier, which contributes to reducing the information cost [36-39]. Second, in CBEC platforms, price and other information are available online and negotiation becomes easy for trading partners when comparing products and carrying out transactions, thus, reducing negotiation costs $[8,40]$. Third, unlike in traditional cross-border trade, the original business and final customers can be connected directly through CBEC platforms, reducing the intermediate steps of transactions, and thus reducing middlemen costs $[8,40,41]$.

However, CBEC is likely to affect trade in goods and services differently [16, 39]. Many products that have traditionally required physical delivery, such as digital media products, can be delivered to customers in digital form via a network, contributing to an increase in services trade [10]. However, although transportation costs for services trade using internet-based delivery is reduced to zero, goods trade still needs physical transportation. Hence, transportation costs continue to play an important role in goods trade compared with services trade. By analyzing data from 117 B2B e-hubs in the apparel and agriculture sectors, Pare [42] found that 
the application of e-commerce in these goods sectors is unlikely to reduce the total transaction costs supporting producer firms to enter new global markets.

Moreover, some studies argue that the impact of e-commerce development is more significant for services trade than goods trade, which is reflected in the ability of e-commerce and digital technology to transform non-tradable services into tradable services. Freund and Weinhold [16, 25] pointed out that an increase of $1 \%$ in Internet use increases the exports of goods by $0.02 \%$, whereas it increases the exports of services more, up to $0.17 \%$. Stare [43] documented that the Internet greatly promotes services trade and expands the scope of tradable services. Through the Internet, many local services become international tradable services with major changes occurring in the travel, entertainment, advertising, financial, and professional services industries. Nath and Liu [28] analyzed data from 49 countries for the period 2000-2013 and found that the development of Information and Communications Technology (ICT) contributed to the growth of all sectors of international services trade. This positive impact is particularly significant in financial and other business sectors. Through analysis of a large sample from multiple countries, Gonzalez and Ferencz [44] found that the impact of increasing digitalization is higher in services sectors, such as telecommunications and computers than in other commodity trade industries. Based on prior studies, we defined our first hypothesis as follows:

Hypothesis 1 The development of CBEC in China will have a more positive impact on its services exports than on goods exports.

Reducing transaction costs through policy intervention can also generate comparative advantages and promote international trade growth. Under the B\&R initiative, the Chinese government implemented many policies to develop CBEC that aim to stimulate international trade with the $B \& R$ countries. These policies include the development of online payments, e-commerce platforms, logistics, customs clearance services, and tariff incentives [45]. For example, Mi et al. [4] and Miao et al. [46] pointed out that CBEC is an important factor in the B\&R initiative, and preferential CBEC policies such as tax refunds and exemption policies launched by the State Taxation Administration have encouraged the Chinese enterprises to export their products to overseas markets. Wang et al. [8] found that with the implementation of the B\&R initiative, CBEC can offset the negative impact of transportation costs by improving logistics, thus, promoting total international trade volumes. Zhai [47] examined the trade effect of the B\&R initiative using data of economies along and beyond $B \& R$ routes. They found that the improvement of infrastructure in transport and communication, which are the key areas in the B\&R initiative, reduces trade costs and, thus, contributes to an increase in foreign market access. In addition, their simulation results show that China's exports to other B\&R countries will increase by $11.4 \%$ in 2030 .

Although scholars have shown that, under the B\&R initiative, CBEC will promote China's total international trade, they did not identify if the promotion policies under the B\&R initiative have a different impact on CBEC with trade in goods and 
services. Hence, we assume that the promotional effect of the B\&R initiative will be greater on services trade than on goods trade, mainly for two reasons. First, services trade is growing faster than goods trade along with the implementation of the B\&R initiative. As discussed by Liu et al. [48], most of the B\&R countries are emerging and developing economies that have a growing demand for not only traditional services, such as transportation, infrastructure, and construction, but also for highvalue-added services, such as technology and finance. Under the B\&R initiative, a broader market is provided for emerging services trade, and CBEC enables exporting these emerging services to B\&R countries. Second, recent policies focused on building a 'Digital Silk Road' that aims to further integrate the digital economy and emerging smart technologies, such as artificial intelligence, big data, and cloud computing, into the $\mathrm{B} \& \mathrm{R}$ initiative, thereby promoting innovation-driven development. This provides a favorable policy environment for CBEC to promote cross-border transactions in high-value service industries, such as technology, finance, and healthcare, further promoting the optimization of industrial structure; for example, the 'China-Pakistan information corridor,' which aims to develop digital investment and financing services [49]. The policy-driven liberalization of services trade is likely to be a factor in explaining the higher growth of the service sectors than the goods sectors in China. Hence, our second hypothesis is as follows:

Hypothesis 2 Under the B\&R initiative, the promotional effects of China's CBEC are greater on services exports than on goods exports.

The geographic distance effect on trade has been widely examined. Starting with Tinbergen [50], a large number of studies estimating the 'gravity equation' found that bilateral trade volume increased with the two countries' economic size, but decreased with the bilateral distance between the two countries. Transport costs and other cross-border trade costs, such as tariffs and regulatory barriers, are found to be the main causes of friction related to the decrease of trade volume with distance [38]. Furthermore, due to increased information-related costs among the geographically distant trading partners, 'informational frictions' is also a factor that impacts the distance-trade relationship [38].

Goods trade is based on a combination of information and physical transport of goods. The rise of the Internet has led some scholars to declare 'the death of distance,' meaning that information cost is no longer related to geographical distance [51]. However, if CBEC can promote the trade of goods depends on sufficiency of the impact that the reduced information costs due to Internet use can have to change the total trade costs and thus change the trade pattern of goods $[8,52]$. While some studies have shown that CBEC reduces the distance effect on trade in goods [53-55], others argue that it has no impact on the relationship between distance and goods trade [16, 52, 56]. For example, Cowgill and Dorobantu [54], who used online trade data between the United States and Canada, found that the impact of distance on online trade was only $10 \%$ of that on offline trade. However, Freund and Weinhold [16] found little evidence to support the role of the Internet in reducing the distance effect, indicating that compared 
with information costs, transport costs play a more important role in determining the pattern of goods trade. Thus, if CBEC contributes to the reduction of distance-related cost in goods trade remains uncertain.

Although goods still need to be physically transported to a consumer following an online transaction that involves transport costs, most online services, such as information and digitalized products, only transfer electronics, with virtually zero transport costs $[25,57]$. Some studies have documented that compared with goods trade, the Internet has a relatively higher impact on the way in which distance influences services [16, 57-59]. Blum and Goldfarb [58] found that a $1 \%$ increase in distance leads to a $3.25 \%$ decrease in demand for culture-dependent services, such as music and games in the United States, whereas for services with a lower cultural taste dependence, such as financial information and software, distance has no effect. Gomez and Bertin [59] analyzed data from 27 EU countries and showed that the distance effect on online trade of services is lower than that on online trade of goods. A $1 \%$ increase in distance causes a decline in the availability of online music by $0.008 \%$, whereas a $1 \%$ increase in distance reduces the availability of albums by $0.016 \%$. In their study, the distance effect on online music suggests that such products are more available in culturally 'nearby' countries. Using data from 39 countries, Alaveras and Martens [57] applied the gravity model and found that distance has little effect on services trade. They explain that digital technology enables consumers to search for the services they prefer, even if they are further away. When online consumers decide to search abroad, they can go much further than in an offline search because of lower information costs. Based on these existing studies, we propose the following hypothesis:

Hypothesis 3 As the level of China's CBEC rises, geographic distance will have less impact on its services exports than on goods exports.

With the increased efficiency of online search and internet-based digital delivery, the transaction costs for services trade continues to fall, and the potential benefits of trade liberalization in many service sectors will increase [29, 60]. Moreover, with the continuous growth of e-commerce, the scope of tradable services will be further expanded. Carayannies et al. [61] documented that e-commerce technology is more likely to improve productivity in the service industries and enhance service trade competence. This implies that the services sector is more easily affected by digital technology compared with other sectors.

In addition, due to convenience and cost-effectiveness, electronic delivery is replacing some traditional transport channels, which is increasingly shifting products from a tangible to an intangible form, leading to a decline in the level of trade in tangible goods. Yousefi [10] pointed out that the growth of trade in digitizable products promotes the transformation from traditional delivery to electronic transmission, thus promoting total trade volume. Through a comparative statistical analysis, they found that services trade in digitizable products showed an upward trend, along with total trade, for the period 1998-2008. Prior studies explored the trade impact of CBEC, but few identified how the impact on goods 
and services trade changes over time. Therefore, based on existing studies, we assume that the impact of China's CBEC on its services exports will increase over time, whereas the impact on goods exports will not increase annually:

Hypothesis 4 The effect of China's CBEC on its services exports will show an annual upward trend, whereas goods exports will not show an annual upward trend.

\section{Methodology and data}

\subsection{The gravity model}

To investigate the effects of CBEC on trade in goods and services, we used the gravity model, a widely used tool for analyzing bilateral trade flows [62-64]. This model links bilateral trade to aggregate demand and supply in importing and exporting countries, and includes transaction costs, transport costs, and other specific trade factors (e.g. free trade agreements) that may influence trade flows. Since its first use in the study by Tinbergen [50], Anderson [65] began developing an economic theory based on the gravity model of product differentiation, and later developed an advanced theoretical model, considering the monopoly competition, increasing returns to scale, and expenditure systems [56]. Moreover, Deardoff [66] showed that the gravity model could be based on many standard trade theories.

The gravity model has been widely used for studying the effect of digital technology on goods trade flows $[16,20,21,24,55,56]$, and estimating the digital technology effect on services trade flows $[25,27,44]$. The framework of the gravity model enables researchers not only to include digital technology, but also to use geographical, institutional, and cultural factors as proxy variables for trade costs, helping to explain in detail the extent to which different trade barriers affect trade flows [24].

In its simplest form, trade between the two countries is positively related to the size of importing and exporting economies and negatively related to the bilateral distance, where distance is construed to include factors that might create trade resistance [67]. The original formulation is

$$
T_{i j}=A \times Y_{i} \times Y_{j} / D_{i j}
$$

where $T_{i j}$ is the trade volume from country $i$ (exporter) to country $j$ (importer), and $A$ is a constant. $Y_{i}$ and $Y_{j}$ denote the gross domestic product (GDP) of country $i$ and $j$, respectively. $D_{i j}$ is the bilateral distance of country $i$ and $j$, which shows that bilateral trade volume increases with the increase in the GDP of the exporting $(i)$ and importing $(j)$ country, but decreases with the increase in distance between the two countries. More generally, by taking the logarithm, we can write it as follows:

$$
\ln T_{i j}=\alpha_{0}+\alpha_{1} \ln Y_{i}+\alpha_{2} \ln Y_{j}+\alpha_{3} \ln D_{i j}+\varepsilon
$$

The coefficients $\alpha_{1}, \alpha_{2}$, and $\alpha_{3}$ present the percentage change in bilateral trade volume $T_{i j}$ with a one percentage change in $Y_{i}, Y_{j}$, and $D_{i j}$, respectively. The distance between countries mainly affects transport costs and, consequently, trade costs. Apart 
from distance, a gravity model often includes other dummy variables such as contiguity, common language, and trade agreements to capture the trade-related costs [44]. In our framework, bilateral distance is the distance between China and the other country, and the dummy variable of contiguity shows if the other country shares a border with China. Countries are more likely to trade with adjacent countries because of the typically lower trade barriers. The use of a common language can reduce the cost of communication, and it also shows the close cultural ties between countries, which usually lead to strong economic ties. The dummy variable of common language indicates if China and the other country share a common official or primary language. Trade agreements reduce formalities and tariffs, leading to a greater trade volume; the FTA dummy shows if the other country signed a trade agreement with China.

\subsection{Empirical models}

To test our hypotheses, we developed the following four models.

\subsubsection{Model 1}

In Model 1, we consider the impact of CBEC on goods and services exports. The dependent variable $(E X)$ is goods $(G E)$ or services exports $(S E)$, whereas the independent variables are CBEC (CBEC), GDP $(G D P)$, distance (DIST), common language (COMLANG), contiguity (CONTI) and FTAs (FTA).

$$
\begin{aligned}
\ln E X_{i, j, t}= & \alpha_{0}+\alpha_{1} \ln C B E C_{i, t}+\alpha_{2} \ln G D P_{i, t} \\
& +\alpha_{3} \ln \operatorname{SDP}_{j, t}+\alpha_{4} \ln D I S T_{i, j}+\alpha_{5} \text { COMLANG }_{i, j} \\
& +\alpha_{6} \operatorname{CONTI~}_{i, j}+\alpha_{7} \text { FTA }_{i, j, t}+\varepsilon_{i, j, t}
\end{aligned}
$$

where $E X_{i, j, t}$ is the goods or services exports volume from China ( $i$ ) to country $j$ in year $t$; $C B E C_{i, t}$ is the trade volume of CBEC per capita of China $(i)$ in year $t$; GDP $P_{i, t}$ is China's ( $i$ ) GDP in year $t$; $G D P_{j, t}$ is the GDP of country $j$ in year $t ; D I S T_{i, j}$ is the distance between China $(i)$ and country $j$; COMLANG ${ }_{i, j}$ takes a value of 1 if China (i) and country $j$ share a common language, and 0 otherwise; $C O N T I_{i, j}$ takes a value of 1 if China $(i)$ and country $j$ are adjacent, and 0 otherwise; and $F T A_{i, j, t}$ takes a value of 1 if country $j$ shares an FTA with China $(i)$ in year $t$, and 0 otherwise.

\subsubsection{Model 2}

In Model 2, we develop an interaction term between CBEC and the B\&R initiative dummy $(B R)$ to evaluate how CBEC affects goods and services exports differently under the implementation of the $\mathrm{B} \& \mathrm{R}$ initiative. The dependent variable $(E X)$ is goods $(G E)$ or services exports $(S E)$, whereas the independent variables are the interaction term $C B E C^{*} B R$, GDP $(G D P)$, distance (DIST), common language (COMLANG), contiguity (CONTI), and FTAs (FTA). 


$$
\begin{aligned}
\ln E X_{i, j, t}= & \alpha_{0}+\alpha_{1} \ln C B E C_{i, t} * B R_{i, t}+\alpha_{2} \ln G D P_{i, t}+\alpha_{3} \ln G D P_{j, t}+\alpha_{4} \ln D I S T_{i, j} \\
& +\alpha_{5} \operatorname{COMLANG}_{i, j}+\alpha_{6} \operatorname{CONTI}_{i, j}+\alpha_{7} F T A_{i, j, t}+\varepsilon_{i, j, t}
\end{aligned}
$$

where $B R_{i, t}$ takes a value of 1 if year $t \geq 2013$, and 0 otherwise; $C B E C_{i, t} * B R_{i, t}$ indicates the interaction between the CBEC trade volume per capita in China $(i)$ with the implementation of the $B \& R$ initiative.

\subsubsection{Model 3}

In Model 3, we include an interaction term between CBEC and distance to evaluate how the CBEC effects on exports vary by distance. The dependent variable $(E X)$ is goods $(G E)$ or services exports $(S E)$, whereas the independent variables are the interaction term $C B E C^{*} D I S T$, GDP $(G D P)$, distance (DIST), common language (COMLANG), contiguity (CONTI), and FTAs (FTA).

$$
\begin{aligned}
\ln E X_{i, j, t}=\alpha_{0} & +\alpha_{1} \ln C B E C_{i, t} * \ln D I S T_{i, j}+\alpha_{2} \ln G D P_{i, t} \\
& +\alpha_{3} \ln G D P_{j, t}+\alpha_{4} \ln D I S T_{i, j}+\alpha_{5} C O M L A N G_{i, j} \\
& +\alpha_{6} \operatorname{CONTI}_{i, j}+\alpha_{7} F T A_{i, j, t}+\varepsilon_{i, j, t}
\end{aligned}
$$

where $C B E C_{i, t} * D I S T_{i, j}$ indicates the interaction between the CBEC trade volume per capita in China $(i)$ with distance.

\subsubsection{Model 4}

In Model 4, we develop an interaction term between $\mathrm{CBEC}$ and time trend to examine how the CBEC impact on goods and services exports changes over time. The dependent variable $(E X)$ is goods $(G E)$ or services exports $(S E)$, and the independent variables are the interaction term $C B E C^{*} t$, GDP $(G D P)$, distance (DIST), common language (COMLANG), contiguity (CONTI), and FTAs (FTA).

$$
\begin{aligned}
\ln E X_{i, j, t}= & \alpha_{0}+\alpha_{1} \ln C B E C_{i, t} * t+\alpha_{2} \ln G D P_{i, t}+\alpha_{3} \ln G D P_{j, t}+\alpha_{4} \ln D I S T_{i, j} \\
& +\alpha_{5} \text { COMLANG }_{i, j}+\alpha_{6} C O N T I_{i, j}+\alpha_{7} F T A_{i, j, t}+\varepsilon_{i, j, t}
\end{aligned}
$$

where $C B E C_{i, t} * t$ is the interaction between the CBEC trade volume per capita in China $(i)$ and a time trend.

\subsection{Econometric methods}

The gravity model with panel data can be examined with fixed effects (FE), random effects (RE), and Hausman-Taylor (HT) estimation. The FE formulation implies that differences across individuals (in our case the importing and exporting country pairs), in what is collectively referred to as 'individual heterogeneity,' can be captured in differences in the intercept term $c_{i}$, which remains constant over time. The general FE model is defined as follows [68]: 


$$
y_{i t}=x_{i t} \beta+c_{i}+\varepsilon_{i t}
$$

Some studies use FE estimation to deal with the possible heterogeneity and endogeneity issues in a gravity model $[69,70]$. In this way, all time-invariant factors that are specific to a country pair as well as other unobservable characteristics (such as political, or economic characteristics) of the country pairs can be captured by the country-pair dummies [71-73]. However, a major shortcoming of the FE estimation is that any time-invariant variables in a gravity model, such as distance, will be absorbed into country pair FE, not allowing the estimation of coefficients on these variables.

The RE estimation arises from the assumption that intercepts of individual units are randomly distributed. The component $u_{i}$ is the random heterogeneity specific to the $i$ th observation, which is constant over time. The model is [68],

$$
y_{i t}=x_{i t} \beta+\left(\alpha+u_{i}\right)+\varepsilon_{i t}
$$

Unlike the FE, the RE estimates allow us to estimate the coefficients for both time-varying and time-invariant variables. However, the major shortcoming in RE estimates is the restrictive exogeneity assumption, namely zero correlation between explanatory variables and random component. Prior studies pointed out that the RE estimates in a gravity model may be biased, as the endogeneity of time-variant or time-invariant variables is particularly likely to be associated with the time-invariant part of the error term $[64,74,75]$.

The HT model, introduced by Hausman and Taylor [76], is a suitable alternative between FE and RE models for estimation in a gravity model. First, in HT estimation, a subset of the explanatory variables is allowed to be correlated with bilateral (country-pair) effects. Second, consistent parameter estimation is also provided for time-invariant variables, such as distance $[64,77]$. The model can be written as follows:

$$
y_{i t}=x_{1 i t} \beta_{1}+x_{2 i t} \beta_{2}+z_{1 i} \alpha_{1}+z_{2 i} \alpha_{2}+u_{i}+\varepsilon_{i t}
$$

where $x_{1 i t}$ indicates exogenous variables that vary over time and are not correlated with $u_{i} ; x_{2 i t}$ indicates endogenous variables that vary over time and are correlated with $u_{i} ; z_{1 i}$ indicates exogenous variables that are time invariant and uncorrelated with $u_{i}$; and $z_{2 i}$ indicates endogenous variables that are time invariant and correlated with $u_{i}$.

The HT estimation includes a three-step instrumental variable regression. The first step is to estimate the FE model of time-varying variables. The second step is to construct the group mean of the within-group residuals by using the estimation results from the first step. Finally, these group means are used as instrumental variables for explanatory variables, and the estimation is similar to a two-stage least squares one $[24,68]$. This method is widely used for gravity models in international trade to solve endogeneity problems $[24,78,79]$.

In our model, as the value of the distance variable and some dummy variables, such as contiguity, are invariant over time and given the prevalence of endogeneity problems in gravity models, we used the HT estimation for our main results. 
It enables us to deal with both shortcomings in FE and RE estimators. Egger [78] and Walsh [75] emphasized the importance of using the HT estimation to obtain consistent estimates in a gravity model.

In our HT estimation, we treated CBEC and FTA as the endogenous variables. Some studies suggest that the relations between digital technology and trade may be endogenous because of the reverse causality [16, 17, 21]. Therefore, digital technology not only influences trade, but the causality is also reverse-trade impacts digital technology. Previous studies have also considered the potential endogeneity in the relation of trade agreements with trade relationships [80]. Rodríguez-Crespo and Martínez-Zarzoso [24] incorporated potential endogenous trade agreements into trade gravity models and used HT estimates to avoid biased estimates.

\subsection{Data sources}

To compare the impact on trade in goods and services, we use two panel datasets in this study. One panel uses bilateral goods exports data of China and 56 B\&R countries for the period 2000-2018, which is derived from the UN Comtrade's [81] International Trade Statistics database, following Kong and Kneller [82]. Although this provides data for China's goods export with 58 B\&R countries, we eliminated Iran and Afghanistan because of the missing GDP data. In addition, the time period selected for the bilateral goods exports panel is 2000-2018 because the data of China's CBEC are available starting from 2000, and the GDP data is available till 2018. The other panel uses bilateral service export data of China with 26 B\&R countries for the period 2005-2015, which we derived from the Organisation for Economic Co-operation and Development's [83] Trade in Value-Added (TiVA) database, following Gonzalez and Ferencz [44]. The collection of services trade data depends on data availability of the TiVA database. All values are measured in USD.

Our main independent variable is the growth of China's CBEC, which we proxied with CBEC trade volume per capita following Wang et al. [8]. The total trade volume of CBEC is referred from the China's E-Commerce Research Center [5], which is in national currency. We converted it into USD using the China/U.S. foreign exchange rate, and divided it by the total population of China. The China/U.S. foreign exchange rate is referred from the Federal Reserve Bank of St. Louis's [84] Federal Reserve Economic database. For the general variables in the gravity model, we collected GDP data from the Word Bank's [85] World Development Indicators database (measured in USD); the data on distance, common languages, and contiguity are from the CEPII's [85] Geography database; and the data for the FTA dummy are from the China FTA Network [86]. The variables of goods exports, services exports, CBEC, and GDP are taken in their natural logarithmic forms for estimation. Table 1 presents descriptive statistics. 
Table 1 Descriptive statistics

\begin{tabular}{|c|c|c|c|c|c|c|}
\hline Variables & Mean & Median & $\operatorname{Max}$ & Min & $\mathrm{SD}$ & Obs \\
\hline \multicolumn{7}{|c|}{ Sample for goods trade } \\
\hline $\operatorname{LnGE}_{\mathrm{ijt}}$ & 20.718 & 20.917 & 25.154 & 11.992 & 2.270 & 1064 \\
\hline $\mathrm{LnCBEC}_{\mathrm{it}}$ & 644 & 4.538 & 6.846 & 1.565 & 1.553 & 1064 \\
\hline $\operatorname{LnGDP}_{\text {it }}$ & 29.147 & 29.260 & 30.242 & 27.823 & 0.821 & 1064 \\
\hline $\operatorname{LnGDP}_{\mathrm{jt}}$ & 24.446 & 24.457 & 28.631 & 19.866 & 1.672 & 1064 \\
\hline $\operatorname{LnDIST}_{\mathrm{ij}}$ & 8.549 & 8.692 & 8.952 & 7.066 & 0.392 & 1064 \\
\hline COMLANG $_{\mathrm{ij}}$ & 0.036 & 0 & 1 & 0 & 0.186 & 1064 \\
\hline $\mathrm{CONTI}_{\mathrm{ij}}$ & 214 & 0 & 1 & 0 & 0.411 & 1064 \\
\hline FTA $_{\text {ijt }}$ & 0.170 & 0 & 1 & 0 & 0.376 & 1064 \\
\hline \multicolumn{7}{|c|}{ Sample for services trade } \\
\hline $\operatorname{LnSE}_{\mathrm{ijt}}$ & 19.477 & 19.482 & 22.531 & 16.186 & 1.555 & 286 \\
\hline $\mathrm{LnCBEC}_{\mathrm{it}}$ & 4.988 & 4.825 & 6.410 & 3.710 & 0.904 & 286 \\
\hline $\operatorname{LnGDP}_{\text {it }}$ & 29.380 & 29.437 & 30.030 & 28.458 & 0.520 & 286 \\
\hline $\operatorname{LnGDP}_{\mathrm{jt}}$ & 25.583 & 25.7450 & 28.463 & 22.563 & 1.357 & 286 \\
\hline $\operatorname{LnDIST}_{\mathrm{ij}}$ & 8.600 & 8.787 & 8.952 & 7.754 & 0.360 & 286 \\
\hline COMLANG $_{\mathrm{ij}}$ & 0.077 & 0 & 1 & 0 & 0.267 & 286 \\
\hline $\mathrm{CONTI}_{\mathrm{ij}}$ & 0.154 & 0 & 1 & 0 & 0.361 & 286 \\
\hline FTA $_{\mathrm{ijt}}$ & 0.297 & 0 & 1 & 0 & 0.458 & 286 \\
\hline
\end{tabular}

Table 2 Panel unit root test of Levin, Lin, and Chu

\begin{tabular}{llllll}
\hline Categories & \multicolumn{2}{l}{ Goods trade } & & & \multicolumn{2}{l}{ Services trade } \\
\cline { 2 - 3 } \cline { 5 - 6 } & Statistics & $P$ value & & Statistics & $P$ value \\
\hline LnEX $_{\text {it }}$ & $-15.6767 * * *$ & 0.000 & & $-6.8911^{* * * *}$ & 0.000 \\
LnCBEC $_{\text {it }}$ & $-27.3484 * * *$ & 0.000 & & $-4.015 * * *$ & 0.000 \\
LnGDP $_{\text {it }}$ & $-14.8188^{* * * *}$ & 0.000 & & $-19.167 * * *$ & 0.000 \\
LnGDP $_{\text {jt }}$ & $-7.6936 * * *$ & 0.000 & & $-8.3363 * * *$ & 0.000 \\
\hline
\end{tabular}

*Significant at $10 \%$;*significant at $5 \%$;***significant at $1 \%$

\section{Empirical results and robustness analysis}

\subsection{Panel unit root test}

We used the panel unit root test of Levin, Lin, and Chu to check the stationarity of our variables because the macroeconomic variables, such as GDP and exports, may be non-stationary. Table 2 reports the results of the panel unit root test for the variables in levels. For all our variables in a logarithmic form, the null hypothesis that there is a unit root (non-stationary) can be rejected at the $1 \%$ significance level, indicating that these variables in levels are stationary. 


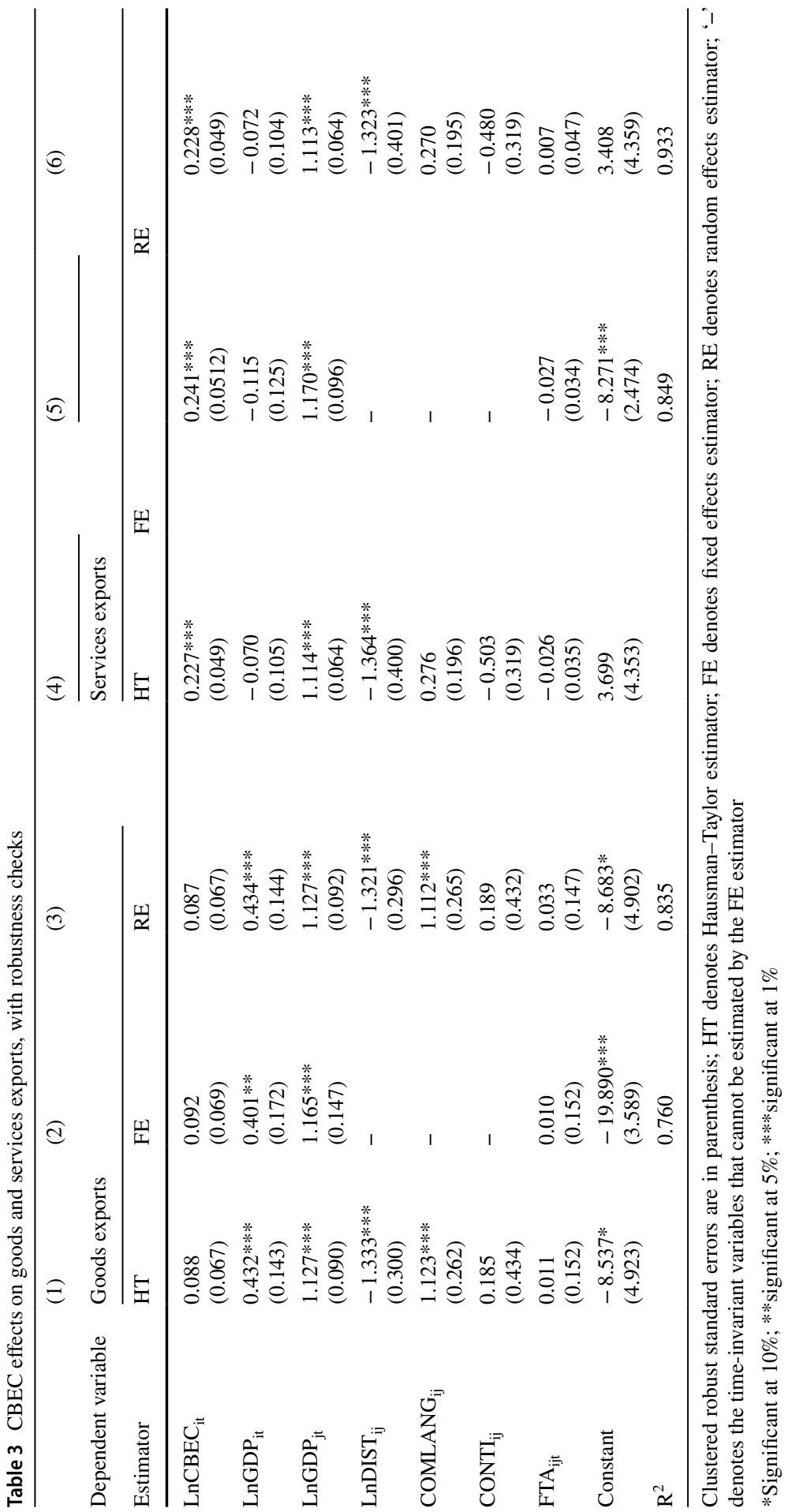




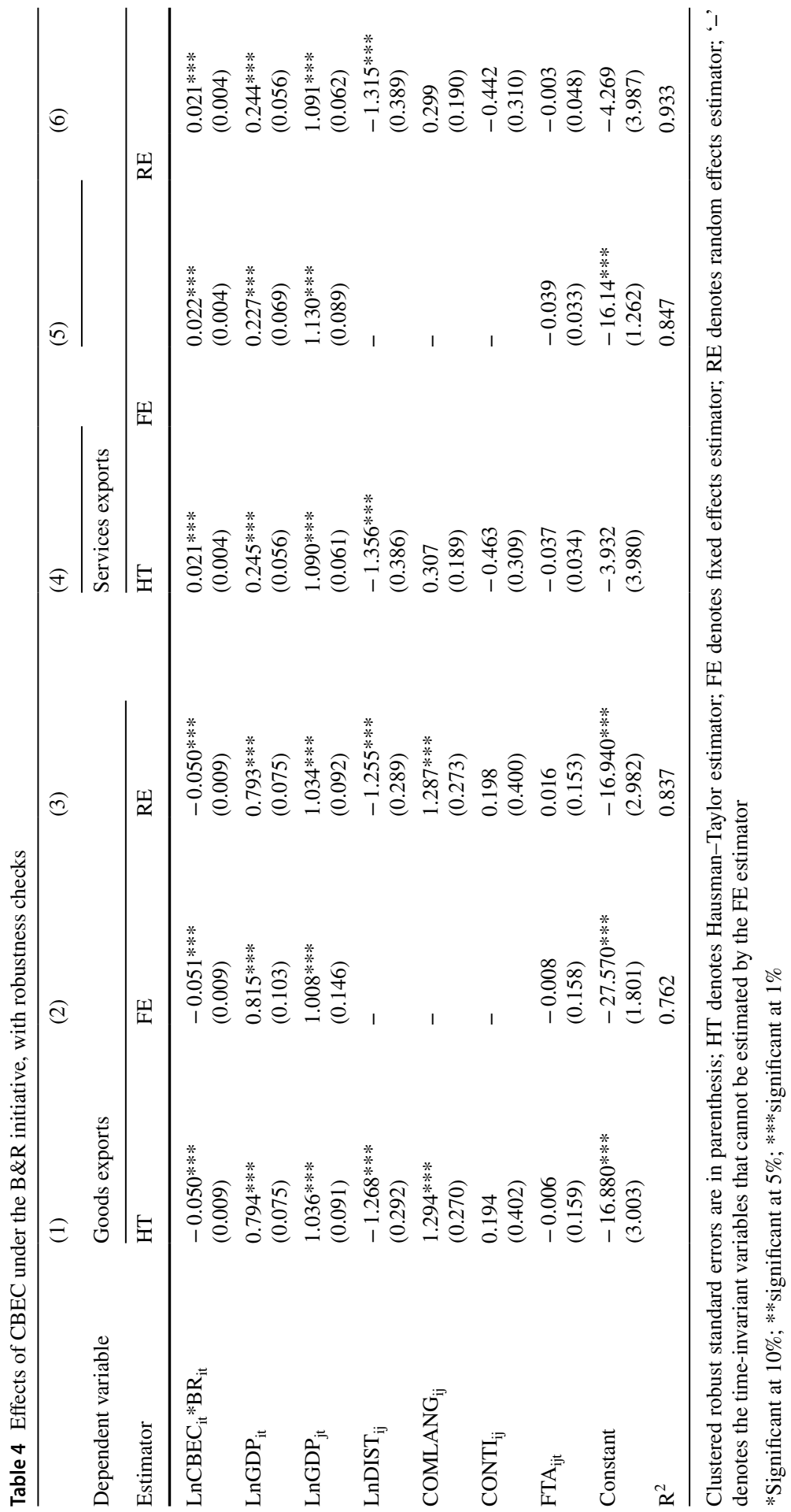




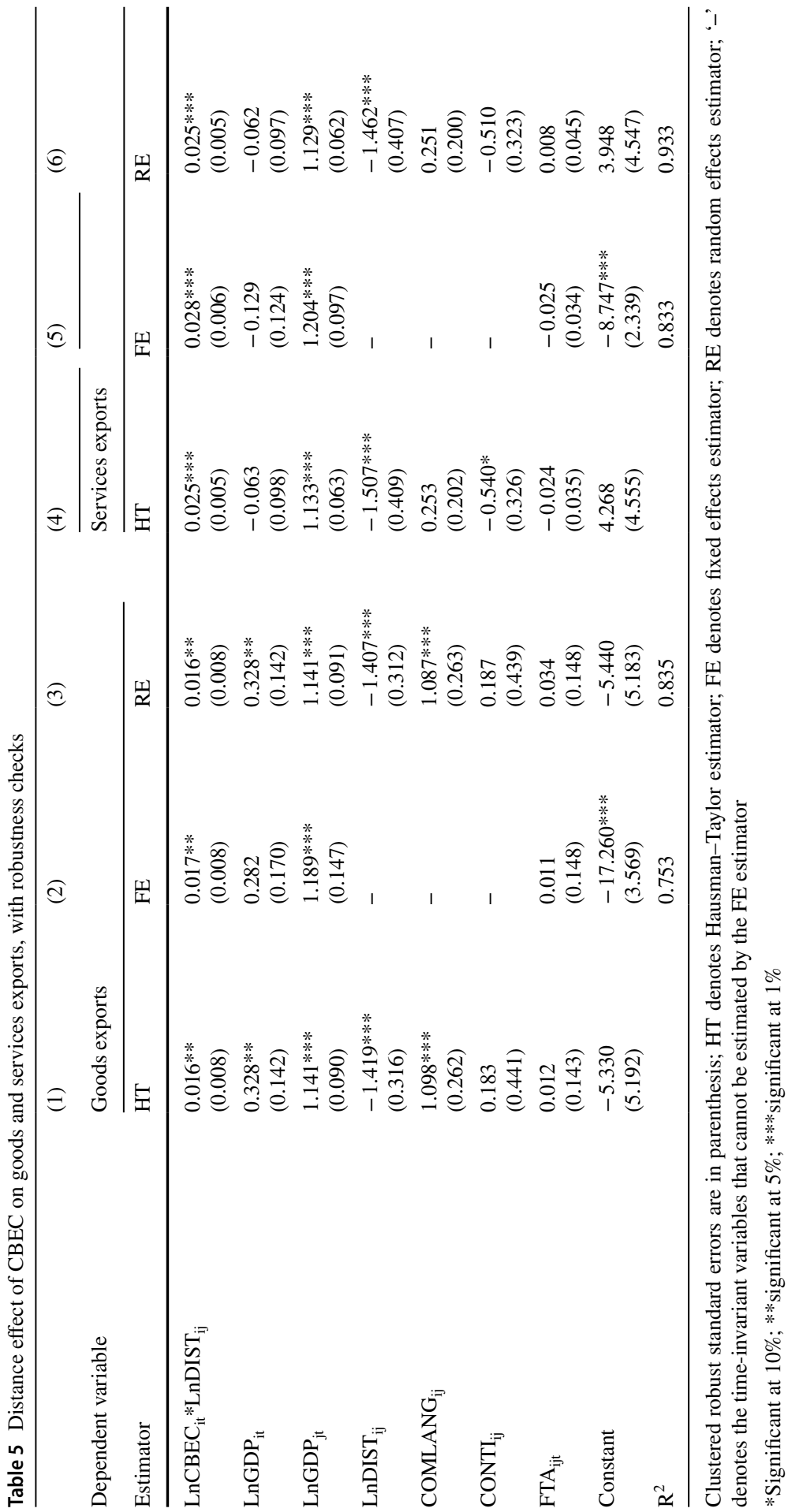




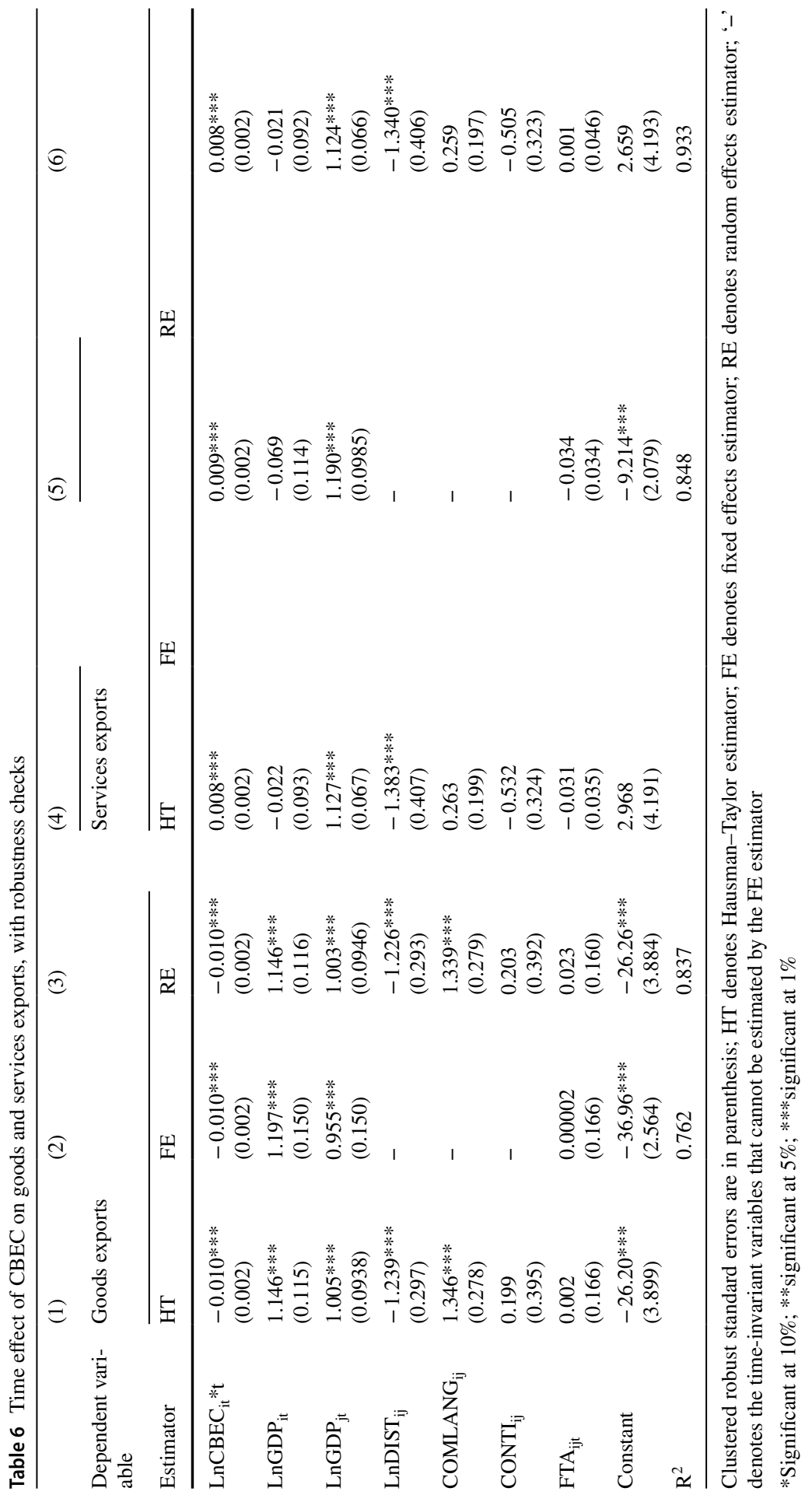




\subsection{Results}

Our estimation results are reported in Tables 3, 4, 5 and 6: Table 3 shows the results for the CBEC impact on goods and services trade; Table 4 presents the $\mathrm{B} \& \mathrm{R}$ initiative effect on the relationship between CBEC with goods and services trade; Table 5 outlines the results for the distance effect of CBEC on goods and services trade; and Table 6 reports the results of the time effect of CBEC on goods and services trade. Our main results are based on the HT estimation as it is more robust and takes into account the endogeneity problems. Moreover, to check the robustness of our main results, we also experimented with FE and RE estimation and used the robust standard errors clustered by country pairs to adjust for the within individual correlation and unobserved heterogeneity [87].

\subsubsection{Comparison of trade in goods and services}

As shown in column (1) of Table 3, the HT estimates for goods exports show that CBEC has no significant impact on goods exports. The GDP of both China and its counterpart country positively affect goods exports at the $1 \%$ level of significance. An increase in China's GDP contributes to a rise in its goods exports by $0.432 \%$, whereas a rise in the importing countries' GDP leads to an increase in China's goods exports by $1.127 \%$. Contrarily, distance negatively impacts goods exports at the $1 \%$ significance level; a rise in the distance between China and the B\&R counterpart country leads to a decrease in China's goods exports by $1.333 \%$. Furthermore, the common language dummy has a positive impact on goods exports at the $1 \%$ significance level. The B\&R countries that share a common official language with China have an increase of $1.123 \%$ in goods imports from China. Contiguity and FTAs have no impact on goods exports.

As shown in column (4) of Table 3, the HT estimates for services exports show that CBEC has a positive impact at the $1 \%$ level of significance. In other words, an increase of $1 \%$ in China's CBEC increases its services exports to B\&R countries by $0.227 \%$. The GDP of the importing country positively affects services exports at the $1 \%$ significance level, whereas China's GDP has no significant impact. Specifically, China's services exports will rise by $1.114 \%$ with a $1 \%$ increase in the importing country's GDP. Contrarily, distance negatively affects services exports at the $1 \%$ level of significance; an increase in distance between China and the counterpart country leads to a $1.364 \%$ decrease in China's services exports. The results for common language, contiguity, and FTAs show no impact on services exports.

To assess the robustness of the main results, we reported the results of FE and RE estimates with clustered robust standard errors in columns (2), (3), (5), and (6) of Table 3. As shown in these columns, the coefficients remain almost unchanged in terms of sign and magnitude compared with the results from HT estimates.

A comparison of the trade in goods and services results shows that the growth of China's CBEC leads to a rise in its services exports to B\&R countries. This is similar to the results of Freund and Weinhold [25], Nath and Liu [28], and Stare 
[43], which indicate a positive impact of digital technology on services trade. The results may imply that reduced transaction costs, caused by the use of e-commerce, led China's services trade to create new competitive advantages and, hence, increase service trade volume. With the development of CBEC, it is possible to export many emerging services, such as technology and financial services, to B\&R countries. However, the results show that CBEC has no impact on goods trade. Unlike many prior studies $[16,20]$ that found that the Internet or e-commerce increases goods trade, our results are consistent with Pare [42], suggesting that transaction costs, reduced by e-commerce use, are not enough to offset the total transaction costs to support Chinese firms exporting commodities to B\&R countries. Bearing this in mind, goods export in China is still challenging despite technological changes. Overall, the results support Hypothesis 1, which suggests a more positive impact of $\mathrm{CBEC}$ on service exports than on goods exports.

\subsubsection{Effects of CBEC under the B\&R initiative}

To examine if the impact of CBEC on goods and services exports is different under the $\mathrm{B} \& \mathrm{R}$ initiative, we analyzed the interaction of CBEC with a dummy variable of the B\&R initiative. The HT estimates in columns (1) and (4) of Table 4 show that after the implementation of the B\&R initiative, CBEC negatively affects goods exports $(b=-0.050, p=0.000)$, but has a positive impact on services exports $(b=0.021, p=0.000)$. The GDP of China has a positive effect on both goods and services exports, with a greater impact on goods exports $(b=0.794, p=0.000)$ than on services exports $(b=0.245, p=0.000)$. Importing countries' GDP has a more positive impact on services exports $(b=1.090, p=0.000)$ than on goods exports $(\mathrm{b}=1.036, p=0.000)$. Distance is more negatively related to services exports $(b=-1.356, p=0.000)$ than to goods exports $(b=-1.268, p=0.000)$. The results for common language indicate a positive impact on goods exports, but no impact on services exports. In addition, contiguity and FTAs have no impact on both goods and services exports.

The results of FE and RE estimates with clustered robust standard errors in columns (2), (3), (5), and (6) of Table 4 also show that the interaction term between CBEC and the B\&R initiative dummy variable has a significant negative sign on exports of goods, but a significantly positive sign on exports of services. In addition, the magnitude of the coefficients is almost the same as that of our main results.

In summary, the results suggest that under the $B \& R$ initiative, the growth of CBEC promotes services exports. To some extent, these results confirm the findings of Liu et al. [48], which indicate that services trade will improve greatly under the B\&R initiative. However, different from the studies of Wang et al. [8] and Zhai [47] — who found that total international trade volume will increase with the growth of CBEC and that the B\&R initiative promotes China's total exports to B\&R countries, respectively - our results suggest that under the $B \& R$ initiative, the promotion policies of CBEC have become a new growth point of China's services exports, but its promotion effect on goods exports had not been effective. These findings support Hypothesis 2. 


\subsubsection{Geographic distance effect of CBEC}

To investigate how the effect of CBEC on exports varies with distance, we introduced an interaction term for CBEC with distance.

The HT estimates in column (1) of Table 5 show that for goods trade, the interaction term indicates a positive impact on goods exports $(b=0.016, p=0.034)$. Hence, for countries with the same distance level, the higher the level of China's CBEC is, the more goods China exports to those countries. In other words, the rising level of China's CBEC reduces the distance effect on goods exports. For other variables, we find that China's GDP $(b=0.328, p=0.021)$, importing countries' GDP $(b=1.141$, $p=0.000)$, and common language $(b=1.098, p=0.000)$ have a positive effect on exports of goods, whereas distance has a negative impact $(b=-1.419, p=0.000)$. Contiguity and FTAs have no impact on goods exports.

The HT estimates in column (4) of Table 5 show that for services trade, the interaction term indicates a positive impact on services exports $(b=0.025, p=0.000)$. Therefore, given the same level of distance, the higher China's CBEC level is, the higher its services exports to B\&R countries will be. Namely, the growth in China's CBEC reduces the distance effect on services exports. In addition, the GDP of the importing countries has a positive impact on services exports $(b=1.133, p=0.000)$, whereas distance $(b=-1.507, p=0.000)$ and contiguity $(b=-0.540, p=0.097)$ have a negative impact. China's GDP, common language, and FTAs have no impact on services exports.

The results of FE and RE estimates with clustered robust standard errors in columns (2), (3), (5), and (6) of Table 5 show that the coefficients remain almost the same as our main results in terms of sign and magnitude.

The comparison of the CBEC distance effect shows that the interaction between CBEC and distance has a more positive impact on exports of services than on exports of goods, supporting Hypothesis 3. Consistent with the findings of Freund and Weinhold [25], Yousefi [29], Alaveras and Martens [57], and Gomez and Bertin [59], our results imply that with the development of CBEC, distance-related costs can be further reduced in China's services exports to B\&R countries. This may be because much trade in services, such as information products, does not incur costs for crossing geographic boundaries, making service transactions still more competitive than goods transactions that require physical transportation.

\subsubsection{Time effect of CBEC}

To investigate how the CBEC effects on goods and services exports change over time, we analyze the interaction of CBEC with a time trend.

In terms of goods trade, the HT estimates in column (1) of Table 6 show that the interaction coefficient of $\mathrm{CBEC}$ and time trend is negative and significant $(b=-0.010, p=0.000)$, indicating that the effect of China's CBEC on its goods exports decreased annually. In addition, the GDP of China $(b=1.146, p=0.000)$ and the importing countries $(b=1.005, p=0.000)$, as well as common language $(b=1.346, p=0.000)$, have a positive impact on goods exports, whereas the distance 
has a negative impact $(b=-1.239, p=0.000)$. Contiguity and FTAs have no effect on goods exports.

For service trade, the HT estimates in column (4) of Table 6 show that the interaction term has a significantly positive impact $(b=0.008, p=0.000)$, implying that the effect of China's CBEC on its services exports increased annually. Moreover, the importing countries' GDP has a positive impact on services exports $(b=1.127$, $p=0.000)$, whereas distance $(b=-1.383, p=0.001)$ has a negative impact. China's GDP, common language, contiguity, and FTAs have no impact on services exports.

The results of FE and RE estimates with clustered robust standard errors in columns (2), (3), (5), and (6) of Table 6 show that the coefficients also remain almost unchanged in terms of sign and magnitude compared to our main results.

In summary, comparing the time effect of CBEC, the interaction between CBEC and time trend show a negative impact on goods exports, but has a positive impact on services exports. This result shows that the effect of China's CBEC on its services exports is on the rise each year, whereas the effect on goods exports is on the decline each year, which supports Hypothesis 4. The results confirm the findings of Yousefi [10] to some extent, which indicate that digital technology has an increasing positive impact on services trade. The rationale may be as follows. Because the efficiency of online search and internet-based digital delivery continues to reduce transaction costs, and the scope of tradable services continues to expand, China's services exports are increasing annually. At the same time, some traditional transport channels are being replaced by electronic transport, such as for digital media products, which will also lead to a decline in trade volume in some commodity sectors year by year.

\subsubsection{Further robustness analysis}

In the initial analysis, the Wald test for group heteroscedasticity has shown that the errors were heteroskedastic. Therefore, to further check the robustness of the results, following Gani and Scrimgeour [88], we applied the panel corrected standard error (PCSE) estimation, which is robust for heteroscedasticity and report the results in Table 7. The PCSE estimator also appears to be broadly consistent with the results from our main findings. The only exception is the interaction term between CBEC and distance on goods exports, which is not significant, but its sign for services exports is still significantly positive and almost remains unchanged. It means that the distance effect attenuation due to CBEC is significant for services trade, but not for goods trade and our hypothesis is still valid. In addition, some studies $[16,56]$ reported that digital technology has no impact on the relationship between distance and goods trade. These results may indicate that although information costs are reduced by CBEC, transport costs still play a more important role in China's goods trade. 


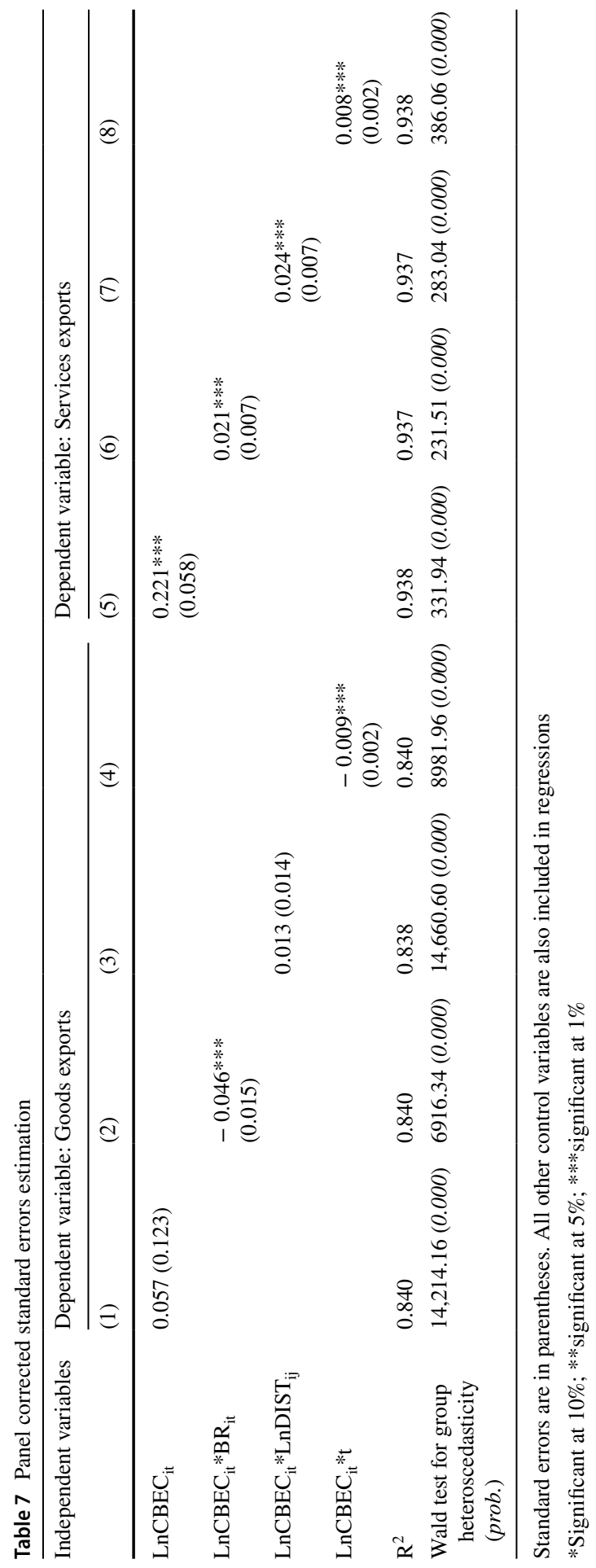




\section{Conclusions, limitations and future research}

In this study, we examined how China's CBEC affects its exports to B\&R countries by conducting a comparative analysis of trade in goods and services using a gravity model. In particular, we examined the different impacts of CBEC on trade in goods and services under the B\&R initiative, as well as the distance and time effects of CBEC on trade in goods and services. Although the findings of the previous studies suggested that the development of e-commerce has an impact on the total volume of international trade, whether and how e-commerce affects trade in goods and services in particular has not been studied yet. Considering the potential of trade in services, it is necessary to understand if CBEC has different effects on these two types of bilateral trade flows because the nature of trade in services is different from trade in goods, especially in cross-border trade.

\subsection{Discussion on the findings}

This study is the first to provide empirical evidence on the differential impact of CBEC over trade in goods and services. First, our research results show that CBEC has a more positive effect on its services exports than on goods exports, indicating that the use of e-commerce in China plays a significant role in promoting its services exports. In China, services trade is growing faster than goods trade which can be explained by the rapid development of CBEC. With the development of information technology and e-commerce, international trade such as information display, trade negotiation, payment and settlement are gradually undergoing digitalization, and commodities in digital forms are becoming an important part of economic activities. In this context, many of the services can be traded over the Internet almost at no cost, resulting in lower transaction costs than goods trade, and bringing a greater potential competitive advantage for services trade. The development of services trade is likely to be the impetus to China's economic development, and the result of our study confirms the importance of CBEC in this industry.

Second, our results indicate that under the B\&R initiative, the promotion effect of CBEC is greater on services exports than on goods exports. As a part of the B\&R initiative, the Chinese government has implemented a number of facilitation policies aimed at promoting trade with countries along the $\mathrm{B} \& \mathrm{R}$ route using e-commerce. In particular, the results emphasize that these policies have a greater impact on trade in services than on trade in goods. This impact may be explained by most of the countries along the B\&R being emerging and developing countries with relatively high demand for emerging service products such as technology and financial services. In this context, the B\&R initiative provides a broader market and a favorable policy environment for the growth of trade in services, making the development of e-commerce a new driving force to boost the export of services, and thus bringing new opportunities for the optimization and upgrade of trade structure in China. In the wave of global digital transformation, it also reflects China's efforts to promote the development of CBEC, expand its market of digital service trade, and actively participate in the division of international service trade in the era of digital economy. 
Third, with the growth of CBEC in China, the distance effect on services exports is more likely to be less than that on goods exports. Increased transportation costs and information-related costs due to distance between two locations increases the trade costs. However, doing business through e-commerce platforms, improves productivity and helps to remove the barriers caused by distance, by offering efficient mobility and easy accessibility to distant knowledge, thereby reducing the cost. In particular, our result indicates that the use of e-commerce reduces the distancerelated costs more in services trade than in goods trade. This is because goods traded through e-commerce platforms still require physical transport, so distance-related costs remain important in online goods transactions. However, many emerging services (e.g., financial services) can be traded over the Internet without the need for producers or consumers to cross geographical borders, significantly reducing the costs associated with distance.

Finally, the results show that the impact of CBEC on service exports increases over time, whereas the impact on goods exports decreases annually. This indicates that compared with trade in goods, the role of CBEC in promoting trade in services has been significantly enhanced year by year. The increased efficiency of e-commerce has caused the transaction costs to continue to decline, and enhanced the competitiveness of service trade. In addition, through the use of e-commerce, previously non-tradable activities (e.g., computing, accounting, research and development) has become tradable, and a wide range of services such as financial, legal, and telecommunications services would increasingly be carried out by CBEC. Therefore, the expanding scope of trade in services is expected to further promote the growth of trade in services.

\subsection{Theoretical contributions and policy implications}

This study is the first to compare and analyze the impact of CBEC on China's trade in goods and services in the background of transaction cost. The findings on the relation between distance and CBEC provides evidence to confirm that e-commerce can reduce the distance-related cost more in services trade than in goods trade, suggesting the significant role of CBEC in enhancing the competence of services trade. Moreover, the results of combining the $\mathrm{B} \& \mathrm{R}$ initiative effect as an interaction variable can be evaluated as having considerable significance. Such evaluations, which can be rarely observed in other studies, highlights the role of e-commerce promotion policies in promoting the export of services, and optimizing the trade structure. Within the research field of CBEC, this study presents the initial exploration of the differential effect of CBEC on trade in goods and services, which is expected to lay the foundation for future research that aims to examine trade effect of CBEC.

Our results also have several policy implications. First, the rising level of China's CBEC promotes its export volumes to B\&R countries, especially for its services. Given the impact of CBEC on international trade, policies should aim to increase investments in the construction of information infrastructure, innovation of crossborder logistics, and the training of CBEC human resources. 
Second, with the implementation of the B\&R initiative, China's CBEC improved its services exports to $B \& R$ countries more, suggesting that the favorable CBEC policies under the $B \& R$ initiative are part of the reason for this increase. The government should use the opportunity afforded by the $\mathrm{B} \& \mathrm{R}$ initiative to better promote China's services trade. In addition, policies to promote CBEC should focus on the development of emerging services industries such as financial and information services, and accelerating the optimization and transformation of the structure of services industries.

Third, CBEC reduces the distance effect on exports, indicating that the growth of CBEC creates new competitive advantages for China's exports, especially those from the service sectors. Bearing this in mind, the government should encourage enterprises to engage in CBEC, improve trade efficiency, and take full advantage of the reduction of trade costs, such as transportation costs and information and market research costs, and reduce trade barriers.

Finally, our findings show that CBEC has a higher effect on trade in services compared with its impact on trade in goods. This result indicates that trade promotion policies have an incrementally better effect on its services trade compared to its trade in goods. To improve the application of CBEC in international trade activities, the government should introduce more promotion policies, reduce legal restrictions related to foreign trade, strengthen public regulations, such as taxation and logistics, optimize infrastructure, and improve customs clearance efficiency.

\subsection{Limitations and future research}

This study mainly analyzed the different effect of CBEC on the trade in goods and services in China. The impact of CBEC on each industry has not been explored. Specifically, if e-commerce has a greater impact on a specific industry than another is not analyzed. Future research, therefore, could analyze the impact of CBEC through in-depth research with more specific data on each industry. In addition, CBEC is applicable to both import and export trade, in our study, we only considered the effect on exports. Future studies, can explore the impact on imports to gain more insights.

\section{Appendix 1: Sample countries}

See Table 8 . 
Table 8 Sample countries

\begin{tabular}{ll}
\hline Category & Countries \\
\hline Goods trade & Albania, Armenia, Azerbaijan, Bangladesh, \\
& Bahrain, Belarus, Bhutan, Bosnia and Herzego- \\
& vina, Brunei Darussalam, Bulgaria, Cambodia, \\
& Croatia, Cyprus, Czech Republic, Estonia, \\
& Georgia, Greece, Hungary, India, Indonesia, \\
& Israel, Jordan, Kazakhstan, Kuwait, Kyrgyzstan, \\
& Latvia, Lao PDR, Lebanon, Lithuania, Malay- \\
& sia, Maldives, Myanmar, Mongolia, Nepal, \\
& North Macedonia, Oman, Pakistan, Philippines, \\
& Qatar, Moldova, Romania, Russian Federation, \\
& Saudi Arabia, Singapore, Slovak Republic, Slo- \\
& venia, Sri Lanka, Tajikistan, Thailand, Turkey, \\
& Turkmenistan, Ukraine, United Arab Emirates, \\
& Uzbekistan, Viet Nam, Yemen \\
Bulgaria, Brunei Darussalam, Cambodia, Croatia, & Cyprus, Czech Republic, Estonia, Greece, Hun- \\
gary, India, Indonesia, Israel, Kazakhstan, Lat- & via, Lithuania, Malaysia, Philippines, Romania, \\
& Russian Federation, Saudi Arabia, Singapore, \\
& Slovakia, Slovenia, Thailand, Turkey, Viet Nam \\
Services trade &
\end{tabular}

\section{Appendix 2: Trend of CBEC in China (2000-2018)}

\section{See Fig. 2.}

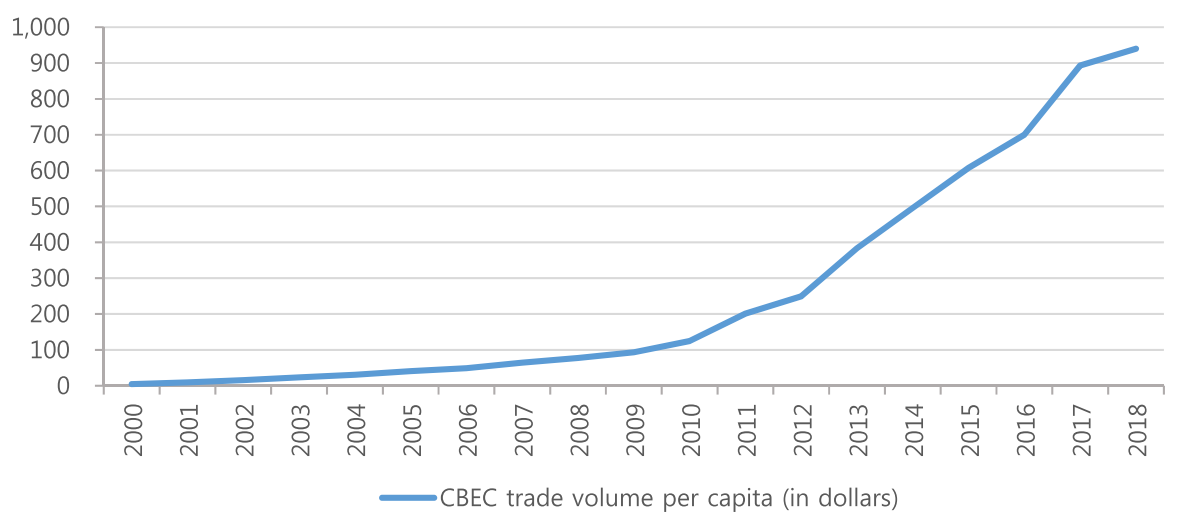

Fig. 2 Trend of CBEC in China (2000-2018). Source: Author's calculation based on the data from China's E-Commerce Research Center [5] 


\section{Appendix 3: Trend of China's goods exports to the sampled countries (2000-2018)}

See Fig. 3.

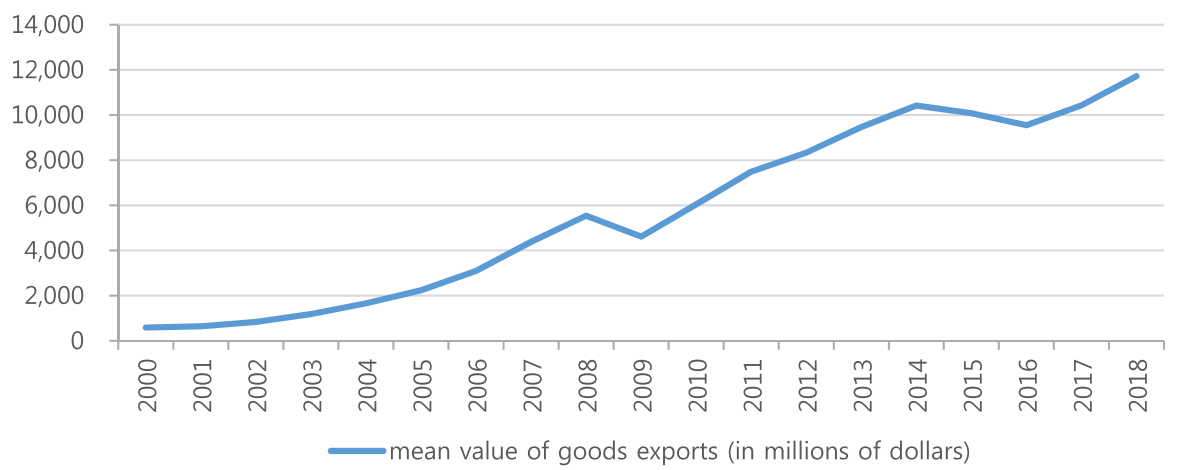

Fig. 3 Trend of China's goods exports to the sampled countries (2000-2018). Source: Author's calculation based on the data from UN Comtrade [81]

\section{Appendix 4: Trend of China's services exports to the sampled countries (2005-2015)}

See Fig. 4.

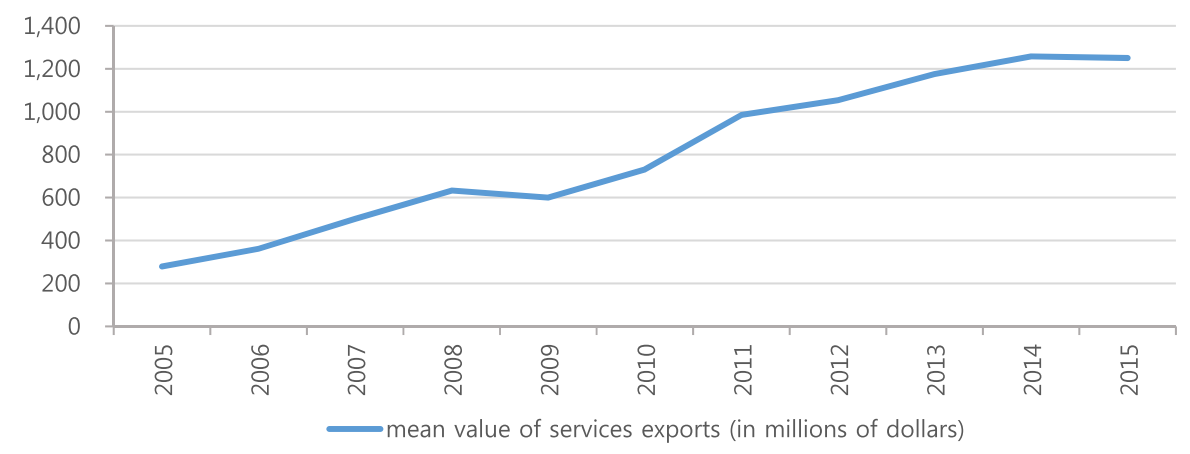

Fig. 4 Trend of China's services exports to the sampled countries (2005-2015). Source: Author's calculation based on the data from Organisation for Economic Co-operation and Development [83] 


\section{Declarations}

Conflict of interest All authors declare that they have no conflict of interest.

Open Access This article is licensed under a Creative Commons Attribution 4.0 International License, which permits use, sharing, adaptation, distribution and reproduction in any medium or format, as long as you give appropriate credit to the original author(s) and the source, provide a link to the Creative Commons licence, and indicate if changes were made. The images or other third party material in this article are included in the article's Creative Commons licence, unless indicated otherwise in a credit line to the material. If material is not included in the article's Creative Commons licence and your intended use is not permitted by statutory regulation or exceeds the permitted use, you will need to obtain permission directly from the copyright holder. To view a copy of this licence, visit http://creativecommons.org/licen ses/by/4.0/.

\section{References}

1. Bergendahl, G. (2005). Models for investment in electronic commerce: Financial perspectives with empirical evidence. Omega, 33(4), 363-376

2. Gökmen, A. (2011). Virtual business operations, e-commerce \& its significance and the case of Turkey: Current situation and its potential. Electronic Commerce Research, 12, 31-51

3. Cui, Y., Mou, J., Cohen, J., \& Liu, Y. (2019). Understanding information system success model and valence framework in sellers' acceptance of cross-border e-commerce: A sequential multimethod approach. Electronic Commerce Research, 19, 885-914

4. Mi, C., Wang, Y., \& Xiao, L. (2020). Prediction on transaction amounts of China's CBEC with improved GM $(1,1)$ models based on the principle of new information priority. Electronic Commerce Research. https://doi.org/10.1007/s10660-020-09434-z

5. E-Commerce Research Center. (2020). Cross-border e-commerce database. https://www.100ec. cn/User/industryData.html. Accessed 8 April 2020.

6. E-Commerce Research Center. (2020). China's cross-border e-commerce market data monitoring report. http://www.100ec.cn/zt/2019kjscbg/. Accessed 15 April 2020.

7. Giuffrida, M., Mangiaracina, R., Perego, A., \& Tumino, A. (2017). Cross-border B2C e-commerce to greater China and the role of logistics: A literature review. International Journal of Physical Distribution and Logistics Management, 47(9), 772-795

8. Wang, Y., Wang, Y., \& Lee, S. H. (2017). The effect of cross-border e-commerce on China's international trade: An empirical study based on transaction cost analysis. Sustainability, 9(11), 2028

9. Xing, Z. W. (2018). The impacts of information and communications technology (ICT) and e-commerce on bilateral trade flows. International Economics and Economic Policy, 15(3), 565-586

10. Yousefi, A. (2018). The impact of cross-border e-commerce on international trade. International Journal of Research in Business, Economics and Management, 2(2), 95-121

11. Houghton, K. A., \& Winklhofer, H. (2004). The effect of website and e-commerce adoption on the relationship between SMEs and their exports intermediaries. International small business journal, 22(4), 369-388

12. Burinskienè, A. (2012). International trade and e-commerce in the practice of enterprises activity. European Integration Studies, 6, 85-93

13. Yue, Y. S., \& Li, B. (2019). Effects of e-commerce platforms on firm export: Evidence from China's industrial enterprises. China Economist, 14(5), 112-127

14. China's Ministry of Commerce. (2020). Annual statistics on imports and exports of goods and services. http://data.mofcom.gov.cn/index.shtml. Accessed 8 May 2020.

15. Clarke, G. R. G. (2002). Does internet connectivity affect export performance? Evidence from the transition economies. In World Institute for Development Economics Research (WIDER) Discussion Paper No. 2002/74. Helsinki: WIDER.

16. Freund, C., \& Weinhold, D. (2004). The effect of the internet on international trade. Journal of International Economics, 62, 171-189 
17. Clarke, G. R. G., \& Wallsten, S. J. (2006). Has the internet increased trade? Developed and developing country evidence. Economic Inquiry, 44(3), 465-484

18. Bojnec, S., \& Ferto, I. (2010). Internet and international food industry trade. Industrial Management \& Data Systems, 110(5), 744-761

19. Lee, J. (2012). Network effects on international trade. Economic Letters, 116, 199-201

20. Biswas, T., \& Kennedy, P. L. (2014). Cross-border trade in the era of the internet. Journal of International Agricultural Trade and Development, 10(2), 150-165

21. Osnago, A., \& Tan, S. W. (2016). Disaggregating the impact of the Internet on international trade. In World Bank Policy Research Working Paper No. 7785.

22. Wang, M. L., \& Choi, C. H. (2019). How information and communication technology affect international trade: A comparative analysis of BRICS countries. Information Technology for Development, 25(3), 455-474

23. Fernandes, A. M., Mattoo, A., Nguyen, H., \& Schiffbauer, M. (2019). The internet and Chinese exports in the pre-ali baba era. Journal of Development Economics, 138, 57-76

24. Rodríguez-Crespoa, E., \& Martínez-Zarzoso, I. (2019). The effect of ICT on trade: Does product complexity matter? Telematics and Informatics, 41, 182-196

25. Freund, C., \& Weinhold, D. (2002). The internet and international trade in services. American Economic Review, 92(2), 236-240

26. Choi, C. (2010). The effect of the Internet on service trade. Economics Letters, 109, 102-104

27. Salmani, B., Pourebrahim, F., \& Saremi, M. 2013.The effect of the Internet on international trade in services: Developing countries' case study. In 7th International Conference on e-Commerce in Developing Countries: With focus on e-Security, Kish Island, Iran.

28. Nath, H. K., \& Liu, L. (2017). Information and communications technology (ICT) and services trade. Information Economics and Policy, 41, 81-87

29. Yousefi, A. (2018). Estimating the effect of the internet on international trade in services. Journal of Business Theory and Practice, 6(1), 65-82

30. Danquah, B. A., \& Chen, D. L. (2017). E-Commerce, exports and imports growth: Casual relations between US and China. Journal of Economics and Sustainable Development, 8(14), 237-243

31. Mou, J., Ren, G., Qin, C., \& Kurcz, K. (2019). Understanding the topics of export cross-border e-commerce consumers feedback: An LDA approach. Electronic Commerce Research, 19(4), 749-777

32. Li, J., Yao, Y., Xu, Y., Li, Y., Wei, L., \& Zhu, X. (2019). Consumer's risk perception on the belt road countries: Evidence from the cross-border e-commerce. Electronic Commerce Research, 19, $823-840$

33. Wang, F., Yang, Y., Tso, G. K. F., \& Li, Y. (2019). Analysis of launch strategy in cross-border e-Commerce market via topic modeling of consumer reviews. Electronic Commerce Research, 19, 863-884

34. Coase, R. H. (1937). The nature of the firm. Economica, 4, 386-405

35. Butter, F. A., \& Mosch, R. H. (2003). Trade, trust and transaction cost. In Tinbergen Institute Discussion Paper No. 03-082/3. Rotterdam: Tinbergen Institute.

36. Rauch, J. E., \& Trindade, V. (2003). Information, international substitutability, and globalization. American Economic Review, 93(3), 775-791

37. Anderson, J., \& van Wincoop, E. (2003). Gravity with gravitas: A solution to the border puzzle. American Economic Review, 93(1), 170-192

38. Anderson, J. E., \& van Wincoop, E. (2004). Trade costs. Journal of Economic Literature, 42(3), $691-751$

39. Terzi, N. (2011). The impact of e-commerce on international trade and employment. Procedia Social and Behavioral Sciences, 24, 745-753

40. Wang, L., Chai, Y., \& Liu, Y. (2015). Qualitative analysis of cross-border e-commerce based on transaction cost theory. In 12th International conference on e-business engineering (ICEBE), Beijing, China (pp. 23-25).

41. Sleuwaegen, L., \& Smith, P. M. (2020). Who purchases cross-border? Individual and country level determinants of the decision to purchase cross-border in the European Single Market. Electronic Commerce Research. https://doi.org/10.1007/s10660-020-09440-1.

42. Pare, D. J. (2003). Does this site deliver? B2B e-commerce services for developing countries. The Information Society, 19(2), 123-134

43. Stare, M. (2003). The scope for e-commerce in central and eastern European countries' services trade. The Service Industries Journal, 23(1), 27-42 
44. Gonzalez, J., \& Ferencz, J. (2018). Digital trade and market openness. In OECD Trade Policy Papers No. 217. Paris: OECD publishing.

45. Ma, S., Chai, Y., \& Zhang, H. (2018). Rise of cross-border e-commerce exports in China. China and World Economy, 26(3), 63-87

46. Miao, Y., Du, R., Li, J., \& Westland, J. C. (2019). A two-sided matching model in the context of B2B export cross-border e-commerce. Electronic Commerce Research, 19, 841-861

47. Zhai, F. (2018). China's Belt and Road initiative: A preliminary quantitative assessment. Journal of Asian Economics, 55, 84-92

48. Liu, X. Y., Chen, Y. N., \& Li, R. (2019). The development of China's service trade under the 'One Belt and One Road' initiative. In Proceedings of 4th international conference on social sciences and economic development (pp. 177-179).

49. Shen, H. (2018). Building a digital silk road? Situating the Internet in China's Belt and Road initiative. International Journal of Communication, 12, 2683-2701

50. Tinbergen, J. (1962). Shaping the world economy: Suggestions for an international economic policy. The Twentieth Century Fund.

51. Cairncross, F. (1997). The death of distance: How the communications revolution will change our lives. Orion Business Books.

52. Gomez-Herrera, E., Martens, B., \& Turlea, G. (2014). The drivers and impediments for cross border e-commerce in the EU. Information Economics and Policy, 28, 83-96

53. Hortacsu, A., Martinez-Jerez, F., \& Douglas, J. (2009). The geography of trade in online transactions: Evidence from eBay and mercado libre. American Economic Journal-Microeconomics, 1(1), 53-74

54. Cowgill, B., \& Dorobantu, C. 2012. Gravity and borders in online commerce. http://www.colum bia.edu/ bc2656/papers/GravityBordersPaper.pdf. Accessed 20 June 2020.

55. Lendle, A., Olarreaga, M., Schropp, S., \& Vezina, P. L. (2016). There goes gravity: eBay and the death of distance. Economic Journal, 126(591), 406-441

56. Chung, K. C., Fleming, P., \& Fleming, E. (2013). The impact of information and communication technology on international trade in fruit and vegetables in APEC. Asian-Pacific Economic Literature, $27(2), 117-130$

57. Alaveras, G., \& Martens, B. (2015). International trade in online services. In Institute for Prospective Technological Studies Digital Economy Working Paper No. 2015/08. Seville: Joint Research Centre (JRC), European Commission.

58. Blum, B. S., \& Goldfarb, A. (2006). Does the internet defy the law of gravity? Journal of International Economics, 70(2), 384-405

59. Gomez, E., \& Bertin, M. (2015). Language, copyright and geographic segmentation in the EU digital single market for music and film. In Institute for Prospective Technological Studies Digital Economy Working Paper No. 2015/04. Seville: European Commission, Joint Research Centre.

60. Panagariya, A. (2000). E-commerce, WTO, and developing countries. In Policy issues in international trade and commodities study series No.2. New York and Geneva: United Nations Conference on Trade and Development.

61. Carayannies, E. G., Alexander, J., \& Geraghty, J. (2001). Service sector productivity: B2B electronic commerce as a strategic driver. Journal of Technology Transfer, 26(4), 337-350

62. Matyas, L. (2000). The gravity model: Some econometric considerations. World Economy, 21(3), 397-401

63. Fidrmuc, J. (2009). Gravity models in integrated panels. Empirical Economics, 37(2), 435-446

64. Baltagi, B. H., Egger, P., \& Pfaffermayr, M. (2014). Panel data gravity models of international trade. In Center for Economic Studies and ifo Institute (CESifo) Working Paper No. 4616. Munich: CESifo.

65. Anderson, J. (1979). A theoretical foundation for the gravity equation. American Economic Review, 69, 106-116

66. Deardoff, A. (1998). Determinants of bilateral trade: Does gravity work in a neoclassical world? In J. A. Frankel (Ed.), The regionalization of the world economy. University of Chicago Press.

67. Krisztin, T., \& Fischer, M. M. (2015). The gravity model for international trade: Specification and estimation issues. Spatial Economic Analysis, 10(4), 451-470

68. Greene, W. H. (2012). Econometric analysis. (7th ed.). Pearson Press.

69. Micco, A., Stein, E., \& Ordoñez, G. (2003). The currency union effect on trade: Early evidence from EMU. Economic Policy, 18(37), 317-356 
70. Egger, P. H., \& Pfaffermayr, M. (2004). Foreign direct investment and European integration in the 90s. World Economy, 27(1), 99-110

71. Cheong, J., Kwak, D. W., \& Tang, K. K. (2015). Heterogeneous effects of preferential trade agreements: How does partner similarity matter? World Development, 66, 222-236

72. Shin, W., \& Ahn, D. (2018). Trade gains from legal rulings in the WTO dispute settlement system. World Trade Review, 18(1), 1-31

73. Campi, M., \& Duenas, M. (2019). Intellectual property rights, trade agreements, and international trade. Research Policy, 48(3), 531-545

74. Baltagi, B. H., Egger, P., \& Pfaffermayr, M. (2003). A generalized design for bilateral trade flow models. Economics Letters, 80(3), 391-397

75. Walsh, K. (2006). Trade in services: Does gravity hold? A gravity model approach to estimating barriers to services trade. In Institute for International Integration Studies (IIIS) Discussion Paper No. 183.

76. Hausman, J., \& Taylor, W. (1981). Panel data and unobservable effects. Econometric, 49(6), 1377-1398

77. Wooldridge, J. M. (2010). Econometric analysis of cross section and panel data. The MIT Press.

78. Egger, P. (2005). Alternative techniques for estimation of cross-section gravity models. Review of International Economics, 13(5), 881-891

79. Cantore, N., \& Cheng, C. F. (2018). International trade of environmental goods in gravity models. Journal of Environmental Management, 223, 1047-1060

80. Baier, S. L., \& Bergstrand, J. H. (2007). Do free trade agreements actually increase members' international trade? Journal of International Economics, 71(1), 72-95

81. UN Comtrade. (2020). International trade statistics database. https://comtrade.un.org/. Accessed 8 April 2020.

82. Kong, Y. F., \& Kneller, R. (2016). Measuring the impact of china's export growth on its Asian neighbours. World Economy, 39(2), 195-220

83. Organisation for Economic Co-operation and Development. (2020). Trade in Value-Added (TiVA) database. https://stats.oecd.org/Index.aspx?DataSetCode=TIVA_2018_C4\#. Accessed 16 April 2020.

84. Federal Reserve Bank of St. Louis. (2020). Federal Reserve Economic Data. https://fred.stlou isfed.org/series/DEXCHUS. Accessed 6 May 2020.

85. Word Bank. (2020). World Development Indicators database. https://data.worldbank.org/indic ator/NY.GDP.MKTP.CD. Accessed 15 May 2020.

86. China FTA Network. (2020). China's Free Trade Agreements. http://fta.mofcom.gov.cn. Accessed 17 May 2020.

87. Griffiths, W. E., Hill, R. C., Lim, G. C., Cho, S. Y., \& Wong, S. S. (2011). Principles of econometrics. (4th ed.). Wiley.

88. Gani, A., \& Scrimgeour, F. (2019). Can trading partner cultural diversity explain trade? Journal of the Asia Pacific Economy, 24(2), 313-327

89. CEPII. (2020). Geography database. http://www.cepii.fr/CEPII/en/bdd_modele/bdd_modele.asp\# bdd. Accessed 13 May 2020.

Publisher's Note Springer Nature remains neutral with regard to jurisdictional claims in published maps and institutional affiliations. 